\title{
Inhibitory and bactericidal power of mangosteen rind extract towards Porphyromonas gingivalis and Actinobacillus actinomycetemcomitans (Laboratory test)
}

\author{
Ina Hendiani*, Dede Hadidjah*, Agus Susanto*, Indra Mustika SP* \\ *Department of Periodontic, Faculty of Dentistry, Universitas Padjadjaran, Indonesia
}

\begin{abstract}
Introduction: The bacteria that cause the occurrence of periodontal disease were include Pophyromonas gingivalis $(\mathrm{Pg})$ and Actinobacillus actinomycetemcomitans ( $\mathrm{Aa}$ ). Mangosteen rind extract is known to have anti-inflammatory, antimicrobial, and antioxidant properties. The extract of the mangosteen rind is altered in gel preparation in order to streamline its clinical application in periodontal disease. The objective of this study was to determine the antibacterial efficacy of mangosteen rind extract against Pophyromonas gingivalis and Actinobacillus actinomycetemcomitans (Aggregatibacter actinomycetemcomitans). Methods: This study was conducted by experimental laboratory. Gel extracts of mangosteen rind with concentrations of $100,50,25,12.5,6.25,3.125$, and $0.78 \%$ were tested against Pophyromonas gingivalis and Aggregatibacter actinomycetemcomitans in agar diffusion method. Results: This study showed that for bacteria Aggregatibacter actinomycetemcomitans minimal inhibitory concentration at $6.25 \%$ with $13.5 \mathrm{~mm}$ zone of inhibition, while the minimal bactericidal concentration at $12.5 \%$ with $14.7 \mathrm{~mm}$ zone of inhibition. Against Pophyromonas gingivalis bacteria, minimal inhibitory concentration was obtained at $1.56 \%$ and a minimum bactericidal concentration was obtained at a $3.125 \%$. Conclusion: Mangosteen rind gel extract can inhibit growth and bactericidal against Pophyromonas gingivalis and Actinobacillus actinomycetemcomitans (Aggregatibacter actinomycetemcomitans).
\end{abstract}

Keywords: Mangosteen rind extract, Porphyromonas gingivalis, Actinobacillus actinomycetemcomitans, Aggregatibacter actinomycetecomitans

\section{INTRODUCTION}

Periodontitis is an inflammatory disease of tooth supporting tissue (periodontium tissue) caused by microorganisms or groups of specific microorganisms resulting in progressive damage to the periodontal ligament and alveolar bone followed by pocket formation, recession, or both. ${ }^{1}$ Chronic periodontitis is the most common form of periodontitis associated with a slow course of the disease, dental support tissue in chronic periodontitis patients will be inflamed and marked by clinical attachment loss (CAL). ${ }^{2}$

Chronic periodontitis is common in adults over 35 years of age. With age, loss of clinical attachment and alveolar bone damage becomes more common and more severe. The prevalence of clinical attachment loss in chronic periodontitis

Corresponding author: Ina Hendiani, Department of Periodontic, Faculty of Dentistry, Universitas Padjadjaran Jl. Sekeloa Selatan No. 1 Bandung, West Java-Indonesia, Phone/Fax:+6222-2504985, Email: inahendiani@yahoo.co.id 
varies from $99 \%$ in clinical attachment loss of more than $1 \mathrm{~mm}$ to $7 \%$ in clinical attachment loss of more than $7 \mathrm{~mm}$. On average per person, 19.6\% of teeth have a clinical attachment loss of more than $3 \mathrm{~mm} .^{3}$

The main etiology of periodontal disease is the plaque bacteria and metabolic products that accumulate around the gingival margin. Pathogenic bacteria that cause chronic periodontitis are categorized as Red Complex dominated by Phorphyromonas gingivalis, Aggregatibacter actinomycetemcommitans. These bacteria produce toxin and enzymes that alter connective tissue, cause bone resorbtion and inhibit the body defense response..$^{4,5}$

Plaque bacteria that accumulate around the gingival margin can support inflammation of the gingival margin. Individual who has a host response that cannot keep up with periodontal bacterial pathogens will cause the gingival inflammation that may extend to apical and lateral to involve connective tissue and alveolar bone. In such conditions it can be said that the individual suffers from periodontitis. ${ }^{6}$

Treatment of chronic periodontitis begins with the initial phase of eliminating all etiologic factor by removing plaque and calculus, correcting bad restoration, treating caries lesions, and doing plaque control.2,7 Plaque, calculus, and necrotic tissue can be removed by mechanical action such as scalling and root planning. However, in severe cases of periodontitis, scaling therapy and root planning alone cannot be good therapies and therefore require supportive therapy such as the use of antimicrobial agents. Antimicrobials can be given either systemically or locally. Administration of local antimicrobial by applying directly to the pocket has the advantage of being directly targeted and not causing toxicity to the body's circulation..$^{2,7,8}$

Antimicrobial agent, other than chemical based also came from herbal ingredients. One of the herbal ingredients being developed is the mangosteen rind that contains xhantone antioxidant, antitumor, anti-allergic, antiinflammatory, anti-bacterial, and antivirus. ${ }^{8,9}$ Xhantone according Torrungruang ${ }^{10}$ has antibacterial activity in the oral cavity, namely alphamangostin. Mangosteen rind contains mangostin classified as xanthone compound which is a yellow phenol pigment that has its color reaction and chromatographic movement similar to flavonoids. Poeloengan ${ }^{12}$ conducted a research which results mangosteen rind extract containing phenol can inhibit the growth of gram positive and gram negative bacteria in vitro. Nguyen et al. ${ }^{13}$ researched that the content of alpha-mangostin in mangosteen rind extract can also inhibit bacterial growth in the oral cavity.

Based on the antibacterial and antiinflammatory activity of mangosteen rind, this research studied about the efficacy of mangosteen rind gel extract to treat periodontal condition in chronic periodontitis. Gel form is chosen because it has properties that are easy to apply and felt comfortable by the patient.

\section{METHODS}

The aim of this study was to determine the antibacterial effect of gel extract application of mangosteen rind as additional therapy after scaling and root planing in patients with chronic periodontitis. This research is quasi experimental, split mouth with before and after treatment method.

The population in this study was patients of chronic periodontitis who came to Dental Hospital Universitas Padjadjaran Bandung in September until November 2014. A total of 14 patients with chronic periodontitis were selected purposively. The inclusion criterias were: patients with chronic periodontitis on minimum 2 sides and on each side there were at least 2 teeth involved; men and women aged 30-65 years; depth of periodontal pocket $\geq 5 \mathrm{~mm}$; did not take antibiotics for at least 3 months. While the exclusion criterias in this study were patients with history of systemic disease and who have a smoking habit.

The tools and research material used were: UNC 15 periodontal probe of Osung, Korea; Ultrasonic scaller; manual scaller; hoe, file, sickle, and chisel; Gracey Curette of Osung, Korea; mouth mirror; explorer; tweezers; nierbekken; cotton roll and cotton pellet; mouthwash; syringe; masks and gloves; hand mirror; stationary; check form; informed consent form; gel of mangosteen rind; alcohol $70 \%$, and povidone iodine.

Plaque was a yellowish white coating attached to the tooth surface, measured by 
plaque index of Loe and Sillness. Gingival bleeding was bleeding that occurs when a probing is measured using a Bleeding on Probing (BOP) index modification according to Ainamo and Bay. ${ }^{12}$

Gingival inflammation is a inflammation characterized by gingival discoloration as measured by Sillness and Loe index. Level of epithelial attachment is the distance from the boundary between enamel and cementum (cementoenamel junction-CEJ) to the bottom of the pocket measured using UNC 15 periodontal probe.

Gel extract of mangosteen rind is a gel containing mangosteen rind extract packed in syringe and applied into the pocket until it overflows to the surface of the gingival margin. Preparation of mangosteen fruit extract gels based on Poeloengan ${ }^{10}$ and conducted at Research and Service Center, Laboratory-Department of Chemistry Unpad. Mangosteens, which are used does not have a crust about $3 \mathrm{~kg}$, dried without being exposed to direct sunlight at room temperature, then crushed to produce a fine (powder) of $500 \mathrm{~g}$. The dried mangosteen rind samples were macerated with EtOH solvent for $3 \times 24$ hours, then evaporated using a rotary evaporator and decomposed into thickened skin extract of the mangosteen fruit.

Procedures of in vitro laboratory implementation were: dilution of serial dilution was performed on 8 test tubes, the concentration of mangosteen rind extracts obtained from tubes were $100,50,25,12.5,6.25,3.125$, respectively, 1.56, and $0.78 \%$; Then added as much as $0.1 \mathrm{ml}$ of inoculum in liquid culture with McFarland standard 0.5 in each test tube (tube I to tube VIII); Then, prepared 2 more tubes of tubes IX and $\mathrm{X}$, each filled $5 \mathrm{ml} \mathrm{BHI}$ liquid broth. Tube IX was added inoculum tang to functions as a positive control, while in tube $X$ was a negative control (not added inoculum). Then incubated for 24 hours with temperature $37^{\circ} \mathrm{C}$. The incubated inoculum was then distreaked with oases and planted on Nutrient agar medium to determine the growth of the colonies. Then, re-incubated for 24 hours at $37^{\circ} \mathrm{C}$. The result observed the colony growth on Nutrient agar media. Cross-checking by spreading with oases and then replanting suspected colonies as MIC, prior colonies and subsequent colonies on Nutrient Agar medium by spreading technique. Inoculum Nutrient Agar result in Nutrient Agar was incubated for 24 hours with temperature $37^{\circ} \mathrm{C}$. Calculated the number of colonies and determined which concentrations were MIC and MBC.

In this research, MIC and MBC measurements were performed by using dilution of mangosteen rinds gel extract series, so that mangosteen rind gel extract concentrations were obtained at 25 , $12.5,6.25,3.125,6.25,3.125,1.56$, and $0.78 \%$.

\section{RESULTS}

In this study the following results were obtained: for Actinobacillus actinomycetemcomitans bacteria: Minimum inhibitory concentration (MIC) obtained at 6.25\%, while Minimum Bactericidal Concentration (MBC) was obtained at a concentration of $12.5 \%$ (Fig. 1). For Porphyromonas gingivalis bacteria: Minimum Inhibitory Concentration (MIC) obtained at concentrations of $1.56 \%$ and Minimum Bacterial Concentrations $(M B C)$ obtained at concentrations of $3.125 \%$ (Fig. 2).

The measurement of inhibition zone was counted in $\mathrm{mm}$ with the measurement of the longest diameter plus the shortest then divided into two (Fig. 3, Table 1 and 2).

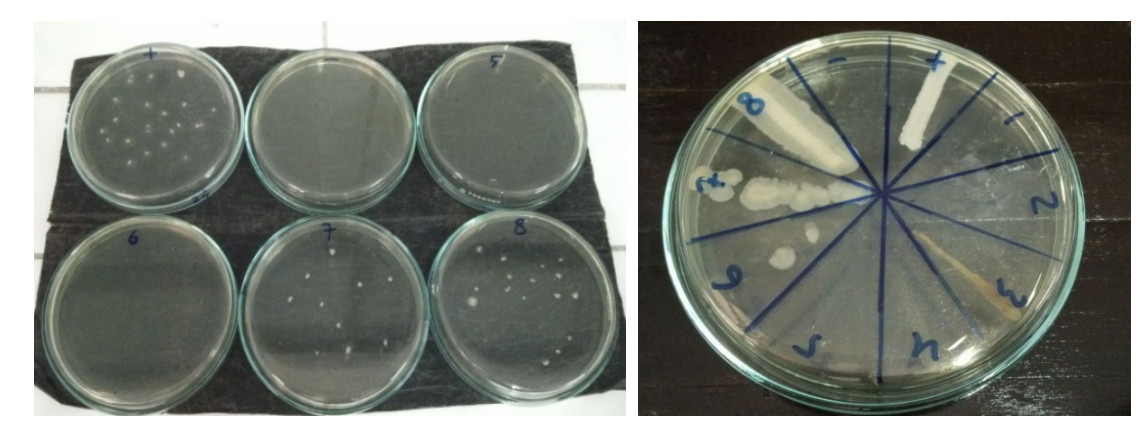

Figure 1. Result of mangosteen colonies count on Aa bacteria and Results of MIC MBC Mangosteen gel against Aa bacteria 

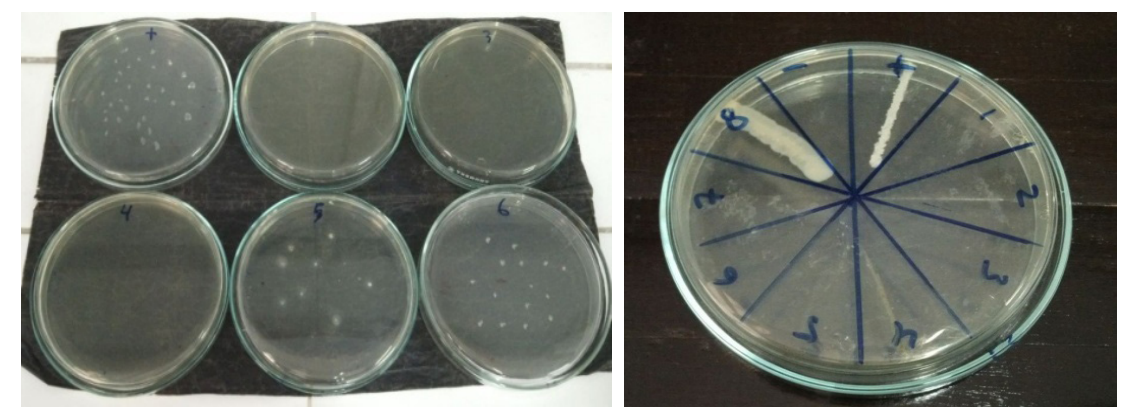

Figure 2. Result of mangosteen colonies count on Pg bacteria and Results of MIC MBC Mangosteen gel towards Pg bacteria.

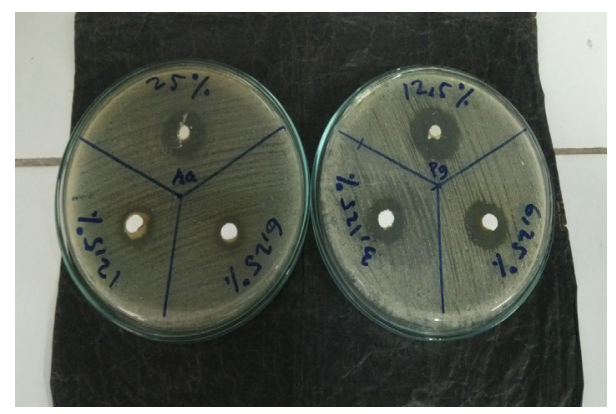

Figure 3. Inhibition zone of mangosteen rind gel extract against bacteria

Table 1. Diameter ( $\mathrm{mm}$ ) of inhibition Aa bacteria to mangosteen rind gel extract (concentration)

\begin{tabular}{|c|c|c|c|c|}
\hline Ingredients & Germs & $25 \%$ & $12,5 \%$ & $6,25 \%$ \\
\hline $\begin{array}{l}\text { Mangosteen } \\
\mathrm{Aa}\end{array}$ & & $\begin{array}{l}\frac{18.0+18.4}{2} \\
=18.2\end{array}$ & $\begin{array}{l}\frac{15+14.4}{2} \\
=14.7\end{array}$ & $\begin{array}{l}\frac{13.8+13.2}{2} \\
=13.5\end{array}$ \\
\hline
\end{tabular}

Table 2. Diameter ( $\mathrm{mm}$ ) of inhibition Pg bacteria to mangosteen rind gel extract (concentration)

\begin{tabular}{lllll}
\hline Ingredients & Germs & $\mathbf{2 5 \%}$ & $\mathbf{1 2 . 5 \%}$ & $\mathbf{6 . 2 5 \%}$ \\
\hline \multirow{3}{*}{ Mangosteen } & $\mathrm{Pg}$ & $12.5 \%$ & $6.25 \%$ & $3.125 \%$ \\
& & $\frac{21.6+20.5}{2}$ & $\frac{17.0+17.0}{2}$ & $\frac{16.3+14.6}{2}$ \\
& & $=21.05$ & $=17.0$ & $=15.45$ \\
\hline
\end{tabular}

\section{DISCUSSION}

The mechanism of mangosteen rind extracts toward dental plaque is that mangosteen rind extract containing xanthone compounds and phenol compounds such as saponins, tannins, and flavonoids will disrupt the metabolic processes of dental plaque bacteria. Xanthone compounds play a role in the process of bacterial inhibition. Saponin will hemolyze cells when saponins meet with bacteria. Flavonoids will bind proteins that interfere with bacterial cell metabolism. Tanin will coagulate bacterial cells and eliminate toxins. ${ }^{10,12}$ Previous research has mentioned that the extract of mangosteen rind is effective in inhibiting the bacterial formation of dental plaque which are Staphylococcus and Streptococcus. The mangosteen rind extract has xanthones whose most potent antibacterial activity is alphamangostin which can be used as a candidate for new plaque control agents. ${ }^{10,12,14}$

Another study conducted by Shan ${ }^{15}$ said that the xanthone material contained in the mangosteen fruit proved effective in maintaining oral hygiene in mouthwash preparations. Research conducted by Torrungruang et al. ${ }^{10}$ said that mangosteen rind contains xanthones consisting of many components, one of which is the most potent 
alpha-mangostin active substance antibacterial activity that can inhibit bacteria in the oral cavity.

Research conducted by Poeloengan ${ }^{12}$ to test the antibacterial activity in mangosteen rind extract in vitro showed that the content of phenol compounds in mangosteen rind extract was able to inhibit the growth of gram-positive and gramnegative bacteria. Another study examining antimicrobials in mangosteen fruit is a study conducted by Nguyen et al. ${ }^{13}$ alpha-mangostin extraction showed effective in inhibiting Streptococcus bacteria in the oral cavity. These can be concluded that alpha-mangostin is a potent glycolytic inhibitor.

Periodontitis is a multifactorial polymicrobial infection preceeded by the presence of gram-negative bacteria such as Porphyromonas gingivalis, Bacteriodis fosythus, Prevotella intermedia, which accumulate in the gingival sulcus. So that the research should be done on the antibacterial actifities of Mangosteen rind extract. Xing-Yu et al. ${ }^{16}$ reported that mangiferin has antibacterial activity in vivo in specific periodontal pathogenic bacteria such as $P$. intermedia and $P$. gingivalis. Mangiferin reduces the loss of alveolar bone in periodontitis. ${ }^{16}$

Poeloengan ${ }^{12}$ reported saponins, tannins, and flavonoids are compounds on the skin of mangosteen fruit that have antibacterial activity. Saponin is an active substance that can increase membrane permeability so that cell hemolysis occurs, when saponin interact with germ cells, the bacteria will break or lysis, flavonoids, is a group of phenol compounds that bind proteins that interfere with metabolic processes. Tannins at concentrations can inhibit the growth of germs, whereas at high concentrations collect protoplasmic germs.

\section{CONCLUSSION}

Mangosteen rind gel extract can inhibit growth and bactericidal against Pophyromonas gingivalis and Actinobacillus actinomycetemcomitans (Aggregatibacter actinomycetemcomitans).

\section{REFERENCES}

1. Kumar P, Ansari SH, Ali J. Herbal remedies for the treatment of periodontal disease-A patent review. Recent Patents on Drug Delivery \& Formulation 2009;3:221-8.

2. Lindhe J, Lang NP, Karring T. Clinical periodontology and implant dentistry. $5^{\text {th }}$ ed. Oxford: Blackwell Munksgaard Ltd; 2008.

3. Albandar JM, Brunelle JA, Kingman A, Destructive periodontal diseases in adult 30 years of age and older in United states 19881994. J Periodont 1999Jan:70(1):13-29.

4. Preshaw P. Etiology of periodontal disease. In: Newman, eds. Carranza's clinical periodontology. $11^{\text {th }}$ ed. St. Louis: Elsevier 2012. p. 481-9.

5. Haffajee A, Socransky S, Patel M, Song X. Microbial complexes in subgingival plaque. Oral Microbiol Immunol 2008; Jun(3):196-205.

6. Novak JM. Periodontal disease. In: Newman MG, Takei HH, Klokkevold PR, Carranza FA. Carranza's clinical periodontology. $10^{\text {th }}$ ed. Philadelphia: Saunders Elsevier Inc.; 2006.

7. Newman MG, Takei HH, Klokkevold PR, Carranza FA. Carranza's clinical periodontology. $10^{\text {th }}$ ed. St. Louis: Elsevier; 2006.

8. Jung HA, Su BN, Keller W, Mehta R, Kinghorn D. Antioxidant Xanthones from the Pericarp of Garcinia mangostana (Mangosteen). J Agric Food Chem 2006:2077-81.

9. Ee G, Daud S, Taufiq-Yap Y, Ismail N, Rahmani M. Xanthones from Garcinia mangostana (Guttiferae). Nat Prod Res 2006;20(12):106773.

10. Torrungruang $K$, Vichienroj $P$, Chutimaworapan S. Antibacterial activity of Mangosteen Pericarp extract against cariogenic Streptococcus mutans. Thailand: CU Dent J 2007:1-10.

11. Lim TK. Edible medicinal and non-medicinal plants. New York: Springer; 2012. p. 83-100.

12. Poeloengan $M$. Uji aktivitas antibakteri ekstrak kulit buah manggis (Garcinia mangostana Linn.). Jakarta: Media Litbang Kesehatan (XX) 2010. p. 65-9.

13. Nguyen PT, Marquis RE. Antimicrobial actions of a-mangostin against oral streptococci. J Microbiol 2011:217-25.

14. Shetty P, Setty S, Kamat S, Aldarti A, Shetty S. Comparison of the antigingivitis and antiplaque efficacy of the herboral mouthwash with chlorhexidine and listerine mouthwash. Pakistan: Pakistan Oral \& Dent J 2013;33(1):76-81. 
15. Shan T, Ma Q, Guo K, Guo K, Liu J, Li W et al. Xanthones from mangosteen extracts as natural chemopreventive agents: potential anticancer drugs. Curr Molec Med 2011;11(8):666-77.
16. Xing-yu D, Qian W, Xue-dong Z, Ding-Ming $\mathrm{H}$. Mangiferin: A possible strategy for periodontal disease to therapy. Medical hypotheses 2010;76. 